胃内分泌細胞過形成を伴う多発性胃カルチノイドの 1 例

\author{
防衛医科大学校第 2 外科, 検查部* \\ 吉住 豊 向井清* 島 伸吾 杉浦 芳章 \\ 米川 甫 大塚八左右 尾形 利郎

\section{A CASE REPORT OF MULTIPLE GASTRIC CARCINOIDS ASSOCIATED WITH GASTRIC ENDOCRINE CELL HYPERPLASIA} \\ Yutaka YOSHIZUMI, Kiyoshi MUKAI*, Shingo SHIMA, \\ Yoshiaki SUGIURA, Hajime YONEKAWA, Hasso OOTUKA and Toshiro OGATA \\ Second Department of Surgery, Department of Surgical Pathology* \\ National Defense Medical College
}

索引用語：胃カルチノイド, 内分泌細胞過形成, 高ガストリン血症

はじめに

カルチノイドは原腸系臓器に分布する内分泌系原基 細胞の腫瘍化により発生する functioning tumor 之考 えられ, 近年血液の内分泌学的検査拉よび免疫組織化 学的検查により分泌ぺプタイドホルモンの同定がなさ れるようになり興味をむたれている。われわれは高が ストリン血症を伴ら多発性胃隆起性病変に術前検查で 胃カルチノイドを疑い, 胃全摘術を施行し, 術後の病 理組織学的検査で胃体部から胃噴門部の萎縮性胃炎,

胃内分泌細胞のびまん性増殖を随伴する多発性胃カル チノイド症例を経験したので報告する。

\section{症例}

患者：61歳, 男

主訴：下腹部痛

家族歴：特記すべきことなし

既往歴：32歳胸膜炎, 33歳胃潰場, ともに内科的治 療で治癒

現病歴: 昭和58年 5 月下腹部痛が出現したため近医 を受診し, 胃 $\mathrm{X}$ 線検查, 胃内視鏡検查を施行し胃上部 に多発性隆起性病变を指摘され精査目的で当院第 2 内 科に紹介され入院した。

入院時現症: 身長 $166 \mathrm{~cm}$, 体重 $53 \mathrm{~kg}$, 顔面頸部正常, 心雑音, 肺ラ音は聴取せず, 腹部は平坦で肝, 脾, 腫 瘤を触知せず。またカルチノイド症候群の臨床症状も 認められなかった。

$<1986$ 年 6 月 16 日受理 >別刷請求先 : 吉住 豊 干359 所沢市並木 $3-2$ 防衛医科大学校第 2 外科

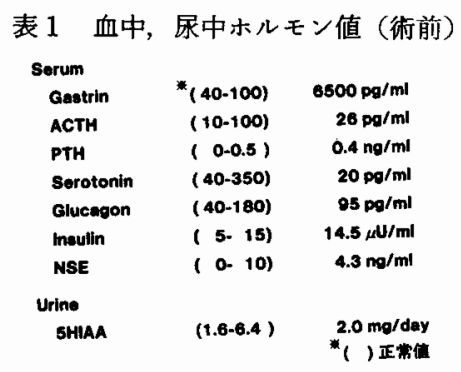

臨床検查所見：赤血球 $487 \times 10^{4} / \mathrm{mm}^{3}$, ヘモグロビン $15.2 \mathrm{~g} / \mathrm{dl}$, 白血球 $5,000 / \mathrm{mm}^{3}$, 分画異常なし, 血小板 $20 \times 10^{4} / \mathrm{mm}^{3}$. 肝機能, 腎機能, 尿検査正常, 便潜血反 応陰性. 血清ガストリンは $6,500 \mathrm{pg} / \mathrm{ml}$ と高値を示し たが，血清 $\mathrm{ACTH,} \mathrm{パラサイロイドホルモン} \mathrm{(PTH),}$ セロトニン, グルカゴン, インシュリン, neuron specific enolase (NSE) は高值を示さず，尿中5HIAA る正常であった（表 1 ).

消化管造影検查：胃 X線撮影では胃上部大弯前壁お 上び後壁におの括の 2 個ずつ小豆大から米粒大の山田 2 型の隆起性病変を認めた(図 1 )。，小腸造影および注 腸造影では異常を認めなかった。

胃内視鏡, 生検検査所見：胃上部大弯前壁および後 壁に打の括の 2 個ずつ山田 2 型の隆起性病变を認めた (図 2).3 個の病変からの生検の病理所見は濃染する 卵円形の核を有する小型の細胞が集族し，小胞巣状に 増殖する腫瘍で, Grimelius 染色陽性でありカルチ， イドが疑われた（図 3).

胃液検查：ペンタガストリン $4 \mu \mathrm{g} / \mathrm{kg}$ 負荷による胃 
図 1 胃X線写真.胃体上部に隆起性病変を認めた(矢 印).

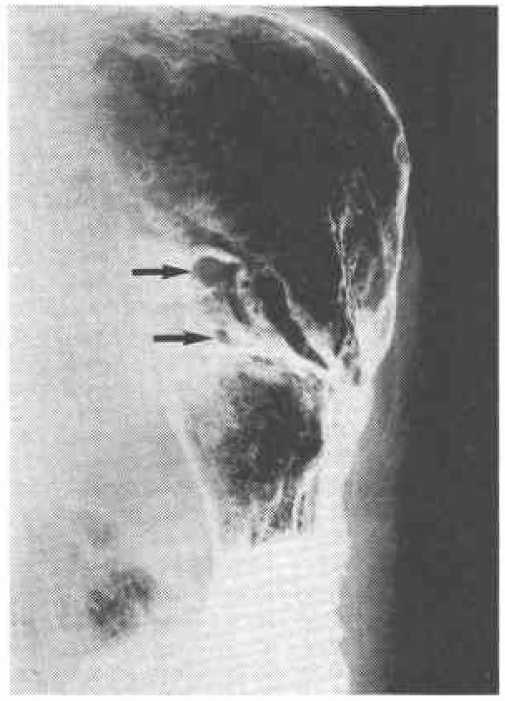

図2 胃内視鏡写真. 胃体上部に山田II 型の隆起性病 変を認めた。

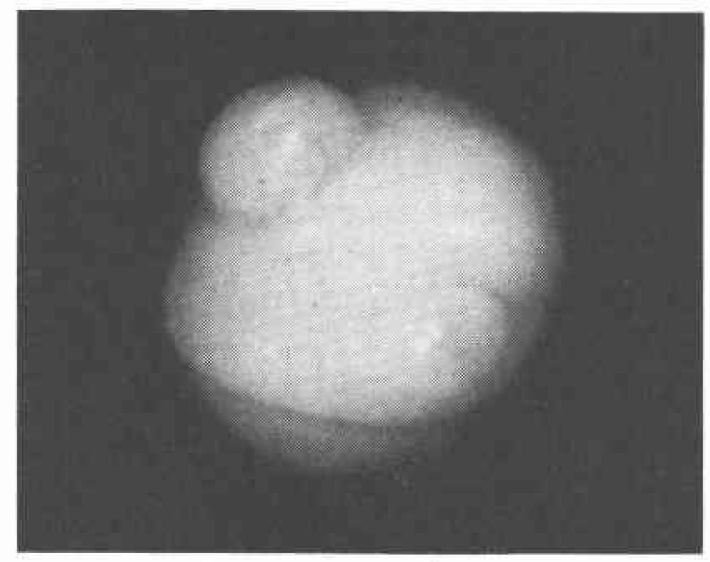

液検查では Basal Acid Output $0.65 \mathrm{mEq} / \mathrm{hr}$, Maximal Acid Output $0.66 \mathrm{mEq} / \mathrm{hr}$ であり，基礎分泌は低 酸であり，ガストリン負荷にも反応しなかった。

以上より胃カルチノイドの疑いのある多発性隆起性 病変の診断で第 2 外科に転科し同年10月 3 日手術を施 行した。

手術所見および術後経過：上腹部正中切開で開腹。 腹水なし, ダグラス窩正常. 肝, 膵, 胆䘫, 小腸, 大 腸に異常を認めず, 胃は浆膜面からは腫瘤は触知せず, リンパ節腫脹もなかった。 胃上部の隆起性病变を含み 胃噴門側切除を施行した，摘出標本の病理学的検討で
図 3 生検組䇅写真. 卵円型の核を有する小型の細胞 が小胞巣状に增殖する腫瘍であった (HE 染色).

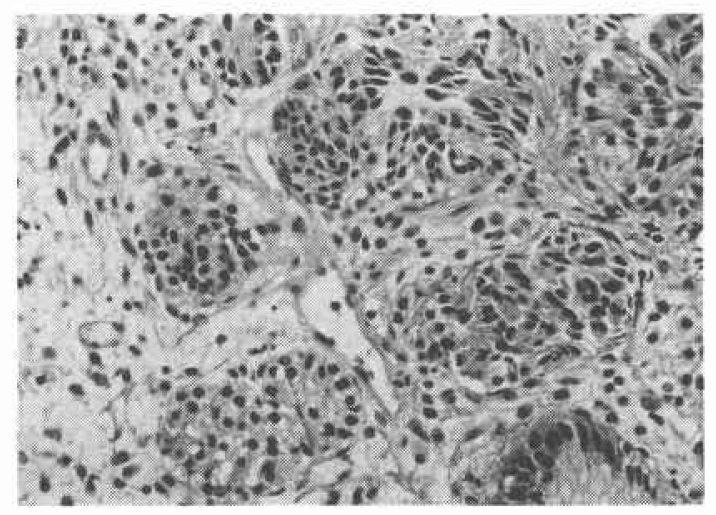

図 4 噴門側切除された標本. 4 個の隆起性病変が認 められた（矢印）。

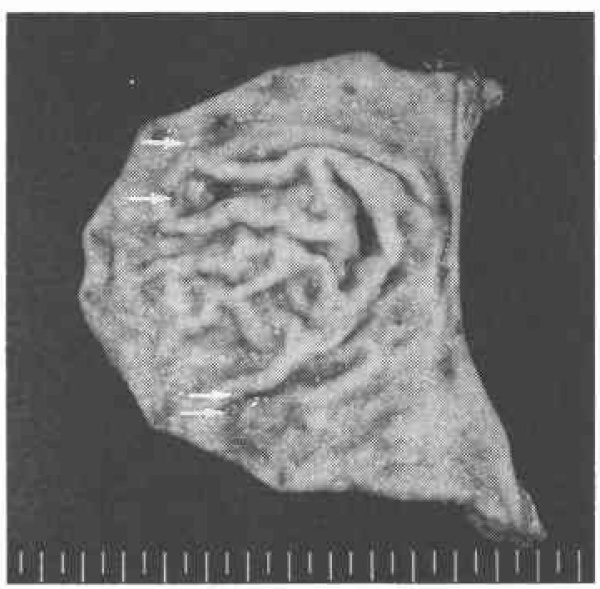

胃上部の隆起性病変以外に内分泌細胞の過形成が厇範 に認められ，さらに microscopic carcinoid tumor が 肚側断端近くに認められたこと，血清ガストリン值も $2,600 \mathrm{pg} / \mathrm{ml}$ と高值を持続したこと, および残胃の生 検で好銀性細胞の過形成を認めたことより残胃内に microscopic carcinoid tumor の残存が強く疑われた ため昭和59年 4 月20日残胃全摘, リンパ節郭清 $\left(\mathrm{R}_{2}\right)^{\mathrm{l})}$ の再手術を施行した。術後経過は良好で, 血清ガスト リン値は術後 1 日目に $25 \mathrm{pg} / \mathrm{ml}$ 上正常に復し, 退院し た. 現在初回手術後 2 年を経過したが再発徵候なく, 外来通院中である。

病理組織学的所見：(1) 肉眼所見：胃上部大弯前壁 に $0.5 \times 0.5,0.4 \times 0.4 \mathrm{~cm}$, 後壁に0.8 $8 \times 0.8,0.5 \times 0.5$ $\mathrm{cm}$ の山田 2 型の隆起性病変を認めた（図 4 ). 再手術 
図 5 カルチノイド腫㾮の病理組織写真。腫瘍細胞は 類円型で，ほぼ均等であり, 結節状に増殖し, Soga 分類のA型であった。（HE 染色）

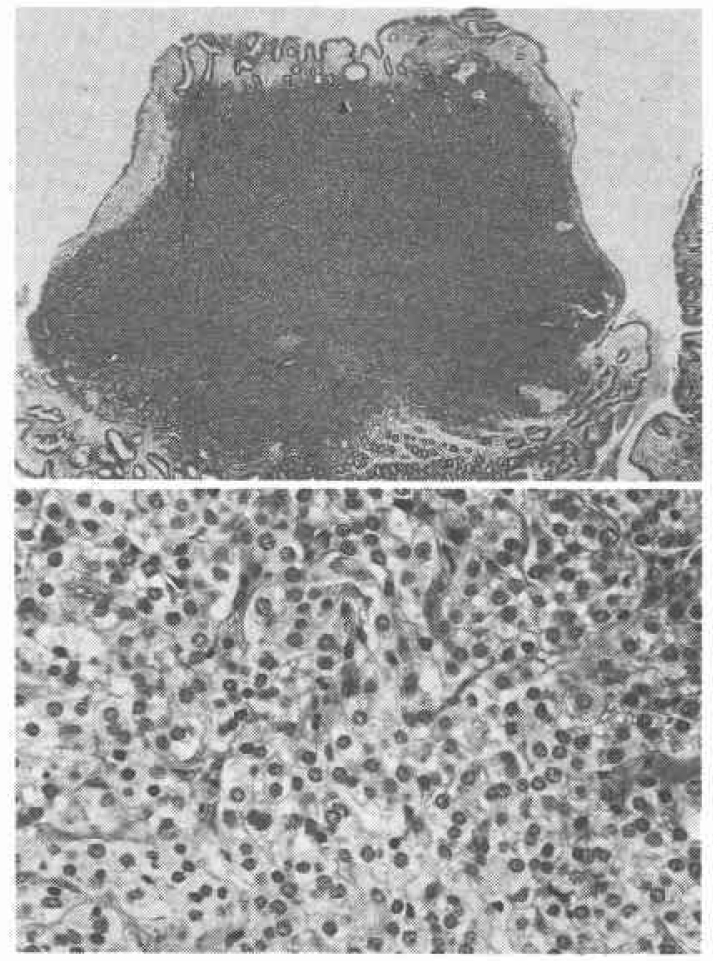

で摘出された残胃内には肉眼的には病変を認めなかっ た.（2）病理学的所見：4 個の隆起性病変は粘膜固有 層から粘膜下層まで浸潤する腫瘍で細胞は類円形，円 柱状でほぼ均等であり結節状に増殖しSoga 分類 ${ }^{2)}$ A型であった(図 5 ). ささらに肉眼的に腫瘍の認められ ない部位に粘膜固有層と粘膜笳板の境界部，一部では 粘膜下層内に小塊状から胞巣状に增殖する内分泌細胞 の過形成を認め, microscopic carcinoid tumor \& 2 個 認められた．再手術で摘出された残胃内にも内分泌細 胞の過形成が胃体中部大弯に認められ， 口側断端近く の大弯に小胞巣が癒合した microscopic carcinoid tumor が認められた. カルチノイド腫瘍および内分泌 細胞の過形成部位は Grimelius 染色陽性, FontanaMasson 染色は前者一部陽性, 後者陰性であった.PAP 法による免疫組織化学的検査では，七ロトニンは前者 陽性, 後者陰性であり, 両者ともガストリン, グルカ ゴン, インシュリン, ソマトスタチン, パンクリアテッ クポリペプタイドは陰性であり, NSE は両者とも陽性 であった（表 2 ）。萎縮性胃炎は胃底部，噴門腺領域に
表 2 特殊染色

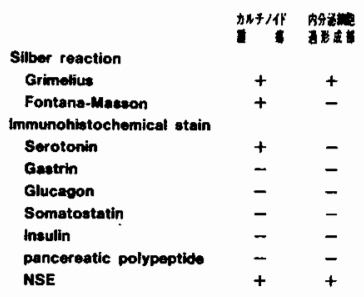

図6 カルチノイド腫瘍の電顕写真. 多数の神経分泌 顆粒が認められた。（10,800倍）

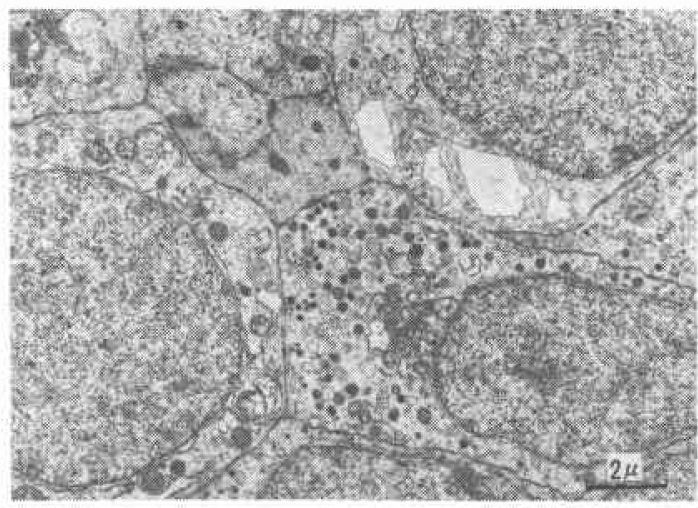

認められたが，幽門腺領域には認められず，免疫組織 化学的検查で幽門腺領域全体にガストリン産生細胞の 過形成が認められた。電顕的観察ではカルチノイド腫 瘍に神経分泌顆粒が認められた（図6）.

\section{考 察}

近年血液の内分泌学的検查および免疫組織化学的検 查により分泌ぺプタイドホルモンの同定が可能になり カルチノイドは functionig tumor として興味をるた れ，報告例散見されるようになってきた．1983年 1 月の胃癌研究会アンケート集計 ${ }^{3)}$ で, 161例の報告がさ れ，胃カルチノイドは一般胃癌に比べて多発の頻度が 高く, 個数も多く, 小さいものが多い傾向にある. 本 例は高ガストリン血症を随伴する無酸症胃に発生した 多発胃カルチノイドで, 病理学的には胃上部の萎縮性 胃炎扎よび内分泌細胞の過形成を伴う症例であったが 同様の症例は本邦で本例を含め 9 例4) 11)報告されて いるにすぎない.

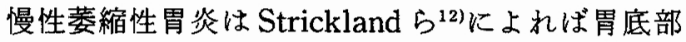
のみ病変の認められる type A と胃底部および幽門部 に病変の認められる type B に分類される. Type A は 全体の20\%をしめ，胃酸は低酸あるいは無酸であり， 
酸による negative feedback 機構により幽門部の G cell hyperplasiaをきたし，高ガストリン血症を随伴す る. 本例当萎縮性胃炎は胃体部，噴門部にのみ認めら れ type A の慢性萎縮性胃炎に属しており，PAP 法に よる免疫組織化学的検查により幽門部ではガストリン 産生細胞の過形成が認められたが，胃カルチノイド， 内分泌細胞の過形成部位ではガストリンを産生してお らず，血中ガストリンは幽門部由来と考兄られた。 Wilander ${ }^{13}$ ) 24 例の胃カルチノイドを集計し無酸症 と胃カルチノイドの関係につき考察を行い, 萎縮性胃 炎を伴ら無酸症胃に発生するカルチノイドは胃体部に 発生し, 多発の傾向がある。その原因として gastrinの trophic action拉よび無酸症による胃液中の carcinogenである nitrosoamine の増加により胃カルチノイ ドが発生すると推察している. 本例も同様の機序が関 与していると考えられた。

治療に関しては，Bordi ${ }^{14}$ は転移のある胃カルチ， イドに胃切除をすることでカルチノイドの増殖が長期 間停止した例を示し幽門洞切除術でるよいと述べてい るが，すべての多発カルチノイドが高がストリン血症 によるものではないこと, 怙よび内分泌細胞過形成と カルチノイドの鑑別がかならずしも容易でないことな どにより ${ }^{15)}$ ，ガストリン産生部位於よび胃体噴門部の カルチノイド, 内分泌細胞過形成部位を同時に切除す る胃全摘術がのぞましいと考完られる。

\section{おわりに}

高ガストリン血症, 胃内分泌細胞過形成を伴った七 ロトニン産生多発性胃カルチノイド症例を経験したの で若干の文献的考察を加学報告した。

御校閲いただいた本学第 2 内科高橋 淳教授に感謝致し ます。

\section{文献}

1）胃癌研究会編：胃癌取扱い規約. 改訂第11版, 東 京，金原出版，1985
2）曾我 淳：カルチノイドの新しい分類の試みと診 断の実際。医のあゆみ $81: 125-128,1972$

3）星 和夫，羽生 丞，竹下公矢ほか：特殊型胃癌 一第40回胃癌研究会アンケート調査報告一。目癌 治療会誌 $18: 134-146,1983$

4）春日井達造, 松浦 昭, 山田栄吉ほか：胃多発性力 ルチノイド。日臨 $35: 318-319,1977$

5）石川 純, 岡島邦雄, 藤井康宏ほか：腫々の発育段 階を示す胃の多発性微小カルチノイドの 1 例. 胃 と腸 $14: 81-87,1979$

6）佐藤幸示, 加藤俊幸, 丹羽正之ほ加：多発性隆起性 病変で発見された胃カルチノイドの 1 例. Gastroenterol Endosc 22:1264-1271，1980

7）安達 弘, 島田信男：胃好銀性細胞のビマン性過 形成を伴ら多発性カルチノイドの 1 症例。日病理 会誌 $69: 342-343,1980$

8）露木 建, 熊井浩一郎, 高見 博ほか：胃体部にび まん性好銀性細胞の堌殖と多発胃カルチノイドの みられた一症例．癌の臨 $27: 1298-1299,1981$

9）佐竹立成, 原 一夫, 林 繁和ほか：きわめて多発 の胃リンパ管内腫晹塞栓を認めた多発性胃カルチ ノイドの 1 症例。癌の臨 $28: 67-73,1982$

10）伊津野稳，渡辺英伸，岩淵三哉ほか：萎縮性胃底腺 粘膜にみられた多発胃カルチノイド。癌の臨 29 : 915-922, 1983

11）星山道夫, 永田成治, 小山芳雄活か：多発胃カルチ ノイドを合併した悪性賓血の 1 例。日消病会誌 $81: 2803-2807,1984$

12) Strickland RG, Mackay IR: A reappraisal of the nature and significance of chronic atrophic gastritis. Am J Dig Dis 18:426-440, 1973

13) Wilander E: Achylia and the development of gastric carcinoids. Virchows Arch 394 : $151-160,1981$

14) Bordi $C$ : Nonantral gastric carcinoids and hypergastrinemia. Arch Surg 116:1238, 1981

15) Grigioni WF, Calleti GC, Marrano D et al: Gastric carcinoids of ECL Cells. Acta Pathol Jpn $35: 361-375,1985$ 